\title{
CONCEPT OF A DEVICE AS AN ANALYTICAL TOOL IN RESEARCH OF ARCHITECTURAL QUEER SPACE
}

\section{A B S S T R A C}

Some analyses of spatial practice in architecture use the concept of architectural structure as a device of perception. Metaphor of a device makes possible to merge static representations of spatial models, with dynamic spatial experiences. In research of architectural queer space, a space produced through self-organized practices, and ignored by architectural discipline, concept of a device as an analytical tool, which confronts of what is lived, to what is conceived, can be fairly useful. I consider the two of devices, one introduced by Beatriz Colomina as a framing device in her analysis of gendered space, and the other one, an orientation device from "Queer phenomenology" by Sara Ahmed. I argue that, at the beginning of normalization, architecture, working as a device of perception, produces queer space, by simultaneous mechanisms of framing and hiding, and orientation and disorientation. The power of these devices is what makes gapping divide in space and society. 


\section{INTRODUCTION : QUEER SITUATION}

It was at the beginning of the millennium in Belgrade that I first tried to bring together two terms, "queer" and "architectural", in order to describe some of my own spatial experiences and to begin a particular research of a hidden and unknown city. This attempt instantly confronted me with a certain methodological trouble. I was trained as an architect, used to think city space as a product of the discipline. And there was seemingly nothing queer in the representation of space produced through (local) architectural discipline, or built structure. There were no places architecturally designed or planed for queers, as if there were no distinct spatial lives of LGBT inhabitants. But much more importantly, the gay/straight division - so obvious in our spatial practices, orientations and positions of the body, and in our daily routine, so tangible in the perceived space intersected by the material structure that hides and isolates, curves and queers that space, so brutally and oppressively built-in between places - that was the division completely ignored in the architectural representations of the space, regardless of the fact that it was the one clearly embodied in architecture. Moreover, the meanings produced in the city of queers, derived from architecture, were left out of architectural discourse.

As in many examples of non-normative spaces, such as those of homelessness, alternative trade, unauthorized migration, self-organized culture, etc., queer situation is established by discontinuity between the two most common notions of "architecture"; between the "architecture" as a professional institutional discipline, and the "architecture" as an inhabited and lived, built environment. It is not that queer space is not produced through the institutions; rather that it has being produced as nonexistent, in spite of its material and symbolical architectural existence made by its inhabitants. Therefore, my research could hardly start from above, from the methodological position concerned with analysis of design or decision-making processes, authors and professional documents. Queer space is here, and it is created from below, through the work of inhabiting and "tactics of self-organisation", in conflict of what is lived and what is planned. To examine the ways of its forming, one would need to take into account personal spatial lives, and bodily practices in a city, as much as design (including several meanings of the word, referring to its conception, process and a product itself). This is why I turned to Lefebvre and his theory of the production of space ${ }^{2}$.

General theoretical approach, based on Lefebvre's ideas, especially with respect to his spatial dialectics that presents the production as a result of three necessary and related concepts: spatial practice, representations of space, and spaces of representation ${ }^{3}$, may offer incisive framework to link quantitative, conceptual, and qualitative information, required to understand the emergence and shaping of architectural queer space. It can also serve as an analytical base 
for considering the architectural structure, in its material and symbolic form, as the one that is at the same time perceived, conceived and lived, and thus produced by people. Lefebvre's point is that "any 'social existence' aspiring or claiming to be 'real', but failing to produce its own space, would be a strange entity, ... and sooner or later disappear..." if it does not "escape from the ideological realm" to the realm of practice and knowledge, or, otherwise stated, from what is lived to what is perceived and conceived. ${ }^{4}$ For this reason, it would not be enough to collect personal reports of queer spatial lives in a city, to defend the view that produced architectural queer space survives. Following Lefebvre's arguments, we also need to present its conceptual model(s) and its specific perceived structure inhabited in a certain routine, both of which are related to its representational spaces, and to each other. That is where my research begins, bearing in mind that what is conceived is not to be found in professional archives (as usual), and that what is perceived is hidden.

In one of my previous papers, regarding gay clubs of Belgrade ${ }^{5}$, I have already argued that conceptual architectural model behind the production of queer space, comes from the (basically popular) discourse, that is developed about and around queers, instead of its reproduction within the architectural discipline. However architecture misses queer objects, queer discourse, for its part, is full of architecture. What I suggested was that the architectural metaphors of (being in, or coming out of) the closet, a room of one's own, (staying inside) four walls, and periphery (or margin), make together a composite spatial model, that appears at all levels of architectural scale, from an interior to a city scale. By drawing on Michael Brown's analysis of the closet, which uses linguistic theories of the metaphor ${ }^{6}$, I tried an analog approach with the four of the architectural metaphors mentioned above. In that manner, I was able to find out and describe the ways they work. On the other hand, I turned to Hillier and Hanson's mapping of "spatial syntax", in order to use some of their methodology to model the architectural structure which is produced around queer body, discursively, by these metaphors. This resulted in finding that a queer body, or any queer place, is always attached/detached to a heteronormative environment by asymmetrical inside/outside connections, and distanced by a series of indirect relations. There are powerful, tangible, visible and fairly solid architectural divisions in the conceived city, between of what is straight and of what is not. LGBT place is removed from central public zone to the inner privacy and, at the same time, to the peripheral otherness. Consequently, the architectural model of the queer space is named the model of "inward peripherization". It was represented as a diagram that demonstrates production of a periphery in the center, surrounding the gay body in the city. 
The story about the inward peripherization was the story about representations of space, about of what is conceived. But it was also tested and found in the perceived and lived space of the inhabitants. In the research of the inward peripherization model, I was following its transfer and its reproduction in(to) the spatial practices, and in(to) the material architectural structure around most of the public LGBT places in Belgrade. However, my aim in this paper is somewhat different. Bearing in mind all the findings regarding the spatial model of inward peripherization, throughout present insight into architectural queer space, I do not intend to discuss a particular conceptual model, or any mode of production of representations of queer space. Here, I want to turn directly to perceived space. Particularly, I want to consider one methodological tool which is sometimes used in the analysis of architecture - concept of architectural structure as a device of perception. I am interested in its queer potential, the potential to reveal what it hides itself. How can the device model be used to analyze queer spatial practice in an architectural environment?

I will start from two fairly similar concepts of architectural structure as a device of perception. One is introduced as a framing device by Beatriz Colomina in her chapter "The Split Wall: Domestic Voyeurism". ${ }^{8}$ The other one comes from "Queer Phenomenology" by Sara Ahmed, as an orientation device. ${ }^{9}$ I will undertake a critical analysis of them in relation to the notion of queer space, and I will try to reinterpret these two concepts as a mode of queer architectonics. I consider Colomina's framing device as a designing tool for reproduction heteronormativity in a gendered architectural environment. My aim is to expose its simultaneous work on the creation of queer places. Unlike Colomina, Ahmed herself is concerned directly with spatialisation of queer body, and her concept of the orientation device is developed to analyze queer space. Still, I would like to elaborate her ideas to the extent that the possible conflict between the orientation of the body, on the one hand, and the orientation produced by an architectural object, on the other hand, becomes central point.

When normalization begins, it begins with new identities and a gapping divide between LGBT places and straight field. This division is manifested in spatial practice of a city and formed by architecture. It makes social space curved and queer. The main hypothesis of this paper is that architecture, working as a device of perception, produces queer space, by mechanisms of framing/hiding and orientation/disorientation. 
Regarding to the notion of queer, queer space can be considered in several ways. If we read "queer" as "an umbrella term for a coalition of culturally marginal sexual self-identifications" 10 , queer space can be seen as a (lived) space of LGBT+ people. If we understand "queer" in terms of queer theory, "queer" is what subverts any normativity, or any identity, not only heteronormativity. ${ }^{11}$ Thus, queer space is the space of problematic normativity and subverted identities. My approach to queer space in this paper is a bit more inclusive. I will analyze it as a space of all the possibilities regarding normalization and identification, a city space as a whole. It includes straight field, as much as gay places, and all the other different positions a body can take in relation to the heteronormative environment. It is not necessary body to have stabile identity ${ }^{12}$ or spatial position. In this paper, "queer body" is the one that crosses gay/straight boundary. At any city location where this boundary emerges, due to spatial disproportion between LGBT places and straight field, it is actually unavoidable that every LGBT body has queer experiences. In contrast, straight bodies may, but are not encouraged to become queer.

\section{FRAMING DEVICES - HIDING DEVICES}

Beatriz Colomina examines the forming of different gender positions in the architectural space of several buildings designed by Adolf Loos and Le Corbusier. She comperes the placement of a body in their structures, using some representations of these projects and objects in speech, as well as in photographs, or in drawings. She points out that controlled permeability of the architectural barrier, which connects/disconnects subjects and objects, is able to regulate contact that can be achieved through body movement in one way, but, in another completely independent way, the barrier can regulate visual contact, or contact by sense of hearing, or other senses. According to the way she makes her argument, that is how the architecture directs and restricts extending of the body into space, and determines significance of its positions. Structure separates and distinguishes places. I would add that meanwhile, the structure is maintaining the impression of spatial continuity, wholeness and unity of the architectural field, and of the world.

In "The Split Wall" Colomina brings together two concepts. The first one is the one of architecture as a scene/auditorium, and another, of gender as performance which is played/observed in such architecture, and established by its mediation. She sheds light on the unbreakable interdependence between the structure and the appearance of the gendered body, and on relative contextual variability of this relationship, which can be far more complex than mere gender segregation in space. 
Compering Loos' and Le Corbusier's architecture, Colomina demonstrates that the division inside/outside is always problematic in an architectural space. That is the case even when it comes to Loss. He, unlike Le Corbusier, turns his inhabitants to the inside. He uses many architectural tools to direct them. He organizes visual barriers, or disposition of openings and furniture. Loos' objects are declaratively opposed to the city environment. But, we see, the more effort is made to produce discontinuity with the city, using the wall with openings and breaks, the more continuity is produced in a repeating mechanism of partial and illusory separation. Subject in a Loos' building is "ensconced in the security of the interior, yet detached from it", "a stranger, and an intruder in his own space", "both inside and outside the object". ${ }^{13}$

The architectural barriers (walls, doors, fences, etc.) with theirs openings Colomina calls framing devices, considering them as an architectural instrument of voyeurism. "Architecture is not simply a platform that accommodates the viewing subject. It is a viewing mechanism that produces the subject. It precedes and frames its occupant." 14 She follows various ways the sight is directed and connected with the movement and the position. And, it becomes evident that while the space is produced by framing devices, the actors are simultaneously on stage and in the audience. The difference between inside and outside appears as a mere illusion, and a body is directed and exposed by its placement. And, what I would make explicit here, architectural continuity of control is uninterrupted.

The truth is that here Colomina is primary concerned with domestic space. But, I do not see any reason not to expand the concept of framing devices to the whole city space, bearing in mind that the architectural tools of space division are the same. Typical architectural division is the one made up of a wall with openings. That wall is split itself, and also splits the inside and outside, so that their border remains problematic. Typical division is the one that disassembles the senses and hence the perception. For instance, visual contact can be encouraged in a place where the other senses are blocked, and where the movement is stopped. In this way, the body becomes controlled, and a single, clearly defined connection between its position and its orientation is established. Most often, as in the city, outer space remains closely observed from the inside, while the interior is controlled from the outside.

This type of permanent surveillance is established from the city level to the level of a room, because every architectural entity has its own structural outside/inside connections, which enable control of the space. Speaking of a continuum of controlled space, embodied by architecture, I am not pointing 
only to surveillance which exists in some disciplinary institutions, such as hospitals, work places, schools and prisons. Probably, they are only the first to think of when it comes to control and discipline through spatial relations, because of well-known Foucault's writings. ${ }^{15}$ Foucault's analysis is, of course, very important for understanding the spatial mechanisms of control, but disciplinary institutions are only a special example, example in which monitoring is (vertical) one-way process. But, more often, architectural space constitutes positions in which the body is simultaneously a subject and an object of control, where movement does not suffer from so many restrictions, and where actors often change roles. This provides horizontal control of everyone over everyone, and, in that manner, also continuity. In contrast, gay/ straight division in the architectural space interrupts this continuity.

Impermeability of gay/straight division is fundamentally different from the usual cuts through social space, made by architectural structure described by Colomina. The division in the architectural fabric is rarely and temporarily total, always on the margins of the structure, to hide undesirable places. But, it turns out that it is the only one suitable for a gay/straight separation, in the case of Belgrade, mentioned above, as well as probably in any other place where the normalization process has just begun. In contrast to the margins, in its central, integrating part, architectural continuum enables theatrical separation of somewhat interchangeable scene and auditorium. The performance of gender division is one of the shows performed in that theater. However, "the split wall," semipermeable structure of connection/division, which materializes this (normative) performance of gender, is not appropriate scenography around the bodies which deviates this performance. Even when it comes to the venues of some LGBT events aimed at increasing the visibility, such as the Pride in Belgrade, whose purpose is achieved by intensifying the paradoxical disclosure through closure, even in that case, the actors on two different sides of the triple fence (made up of police cordon and buildings) do not have the possibility of direct contact, including the absence of visual contact. This is very different from the usual indoor/outdoor division in architecture; an intersection that keeps certain (still controlled) contact between both sides, and thus the continuity of various places.

Colomina also observes the role of framing devices in production of gendered places, rooms, or positions. This analysis may not be as much developed as one would expect in relation to the title of the editorial where it is published, but it does point out to the ways of gendering space of home. For example, it is presented that woman's places are the places of family communication, 
places at the intersection of visible and hidden, on the threshold of public and private, key places to maintain domestic life, and also the places where the body is exposed to view as an object of desire. In contrast, man's places are peaceful places of control, unexposed and quiet. An important point comes up in this analysis - gender is not always only a matter of segregation, but of the way a body appears in a room. Through different systems of representation (of Loos' and Le Corbusier's architecture), we can see that women's and man's positions are not always the same. The pivot of the Loos' house is female, but, in Le Corbusier's villa, it is male. Seems like it is not especially important what the exact distinction is between male and female body, but that distinction is always present in some way, architecturally maintained by framing devices.

Of course, forming of gender is performed at home as anywhere else. It is enough to look at "Gendered Spaces" by Daphne Spain ${ }^{16}$, to realize that the most diverse city places, from work spaces and administration, to schools, are largely marked by it. Spain's research is focused on various, more or less distant histories, and it is based on spatial segregation of two genders. She is often referring to the inequality of social power, created by the difference in the availability of means and knowledge, and by secrecy. I believe this approach reveals only one of the modes of spatial gender production, the one which is related mainly to the division of labor and class inequality. Certainly, there are other modes, such as those described by Colomina, but whatever they may be, they are always performed before one's eyes (and other senses).

Architectural fabric maintains subject/object roles of bodies, and produce different gender positions/orientations. It reaches to the point of the very possibility of surveillance and control, whether in public or in domestic space. In that manner, it reaches often to the very surface of the body. Skin and clothes sometimes becomes its edge. Still, there are lines of built boundary which interrupts this fabric; there are marginal lines, closed walls that prevent surveillance, opaque membranes. It is where the architectural structure becomes the architecture of structure, hidden construction of the world. Through its invisible spaces, pipelines and ducts go. There are attics in there, there are basements, technical and service rooms, shelters, stockrooms, closets, and, after all, gay places themselves are in there.

For instance, neither gay pub, nor bar in Belgrade, has ever had any visual contact with the environment, not to mention the cruising areas and nightclubs. Yet, they are not always located in basements, or passages, or other places isolated per se. If a gay place was situated on street frontage, the windows 
were always closed with opaque sheets, screens, or blinds, or hidden behind the fence in the depth of a terrace, the entrances withdrawn from the streets, or locked. It is interesting to note that one of these bars, Smiley - the oldest among those that still works nowadays, with the entrance and window opened to a passage for pedestrians away from the street frontage - has a window that at opens floor level in the summer months. Only guests' feet under the bar yet can be observed from the outside, but their identities and activities remain hidden. This is fully in line with Le Corbusier's quotation of Loos - Loos who was obsessed with detaching the inhabitants from the environment - "A cultivated man does not look out of the window; his window is a ground glass; it is there only to let the light in, not to let the gaze pass through."17

In a heteronormative city sustainability of gender division is as much a matter of visibility and voyeurism, as much as a matter of invisibility and looking away. Subversive subjects/objects need to be removed from the stage. Coulisses around them detach gender performance from the rest of the world. Membranes around LGBT places are full. They are only parts of frames of framing devices, not complete frames themselves. They direct a glance away. That is how the gay/straight boundary is different from the one which produces gender and (hetero)sexuality of places with Colomina's framing devices. The means of redirection of movement and perception are the same, but the gay/ straight boundary directs away from (instead of toward) an object of perception. Its structural device is not a frame, but a closed, opaque membrane, a hiding device.

\section{ORIENTATION DEVICES - DISORIENTATION DEVICES}

Let's try to look more closely to the very mechanism of spatial relations that forms (queer) sexuality, relations between the bodies and architecture on both sides, and on the very barrier of the gay/straight division in the queer space. The idea of sexuality as an orientation, as a direction in space, could be helpful. It is one of the most common and most accepted ways to talk about sexuality. At the same time, such an idea is an excellent starting point for an examination of spaciousness of sexuality. The key work about orientation and spatial sexuality of body is "Queer Phenomenology" by Sara Ahmed. There are several approaches to theorising spaciousness of sexual and sexualisation of space conceived by Ahmed, which I intend to follow and develop here, in order to describe vectors between (queer) bodies and surrounding architecture. 
Ahmed starts from the writings of Husserl, Heidegger and Merleau-Ponty, as well as from feminist, queer and anarchist theories. Some of her postulates, all of them related to each other, are very relevant here. The first one is the concept of orientation, and the associated concept of disorientation of the body, as a way of shaping its sexuality. The other one is the notion of an orientation device, as an object which affects one's direction, but not as a target of one's orientation. Yet another one idea is that of a norm as an alignment, or, in other words, of a normalization as bringing into (straight) line.

I will try to take a bit further some Ahmed's ideas. She writes about orientation as a way in which the body inhabits space, and in which the body shapes contours of that space, through the relations of proximity and distance. The idea, which basically comes from phenomenological intentionality, that the focus of mind and body towards an object enables extending into space, and shaping it, Ahmed supports with the understanding that the orientation towards something is simultaneously turning away from something else. It seems to me that this interpretation itself is enough to explain the existence and survival of gapping queer (gay/straight) divide. For this reason, I will continue to consider simultaneity of orientation towards (an object), and away from (another object), as a concept of division in (queer) space. I also intend to take further the concept of orientation devices, which refers to objects that turn us in a certain direction. At the same time, these objects can be seen as the one which turn us away from, and may redirect and confuse us. They may become disorientation devices.

Using these concepts I research mechanisms of spatial relations of the body in architectural queer space, especially paying attention to its orientation and position. At the binning of her book, Ahmed implicitly accepts the permanency between the orientation and position. She writes: "If we know where we are when we turn this way or that way, then we are oriented." 18 Regarding this, we could not conclude anything but that the position is firmly linked to the orientation, and that they are mutually determined. Further in her analysis, in a review of the difference in the interpretation of orientation made by Kant and Heidegger, the interdependence between the orientation and position still exists. Kant sees the distinction between the sides of the body, in other words, knowledge of the positions on the body, as a condition for the possibility of spatial orientation. Heidegger, for his part, considers the knowledge of the environment and its familiarity as a way to orient and extend oneself into space, aligning the body with objects. ${ }^{19}$ 
However, thinking about finding one's way in an unknown room, which is not part of his or her memory map, soon enough, Ahmed notes that knowledge of one's position is not a necessary condition for his or her orientation, and vice versa. She also notices that distinguishing between strange and familiar environment is not so strict. "But 'getting lost' still takes us somewhere; and being lost is a way of inhabiting space by registering what is not familiar: being lost can in its turn become a familiar feeling. ${ }^{.20}$ Hence, the direct causality between position and orientation can become destabilized.

According to hypothesis of phenomenology, having an orientation always means having an orientation towards something, towards an object. Orientation is a matter of intention, movement, and focus. However, we can orient unsuccessfully, aiming at an object which is dissipating, or is not present at all. In that situation we become disoriented, though we still keep orient ourselves. Having an orientation and being oriented is not always the same thing. The former suggests an active role of the body in its space, an agency of becoming a subject by extending towards its objects. The latter suggests a bit more - it is a harmony between an active and passive role, between body as a subject, and body as an object. Being oriented is not only about how body turns towards objects, but also how objects turn towards (and not away from) body. There is no doubt that in an ideal, flat, normal space, space without secrets and hidden places, having orientation and being oriented are the same thing, related to having position. The body is here, and that is point from which the world, there, easily unfolds. In such a space the body is familiar with the environment, and inhabits it comfortably. Any object is available, and orientation is as much about feeling at home, as finding way through the world. That is why the existence of a place where you feel at home, of your position, is a question of normalization of the world. Otherwise, "when bodies do not extend into space, they might feel 'out of place' where they have been given 'a place'. Such feelings in turn point to other places, even ones that have yet to be inhabited." ${ }^{1}$ These are moments when orientation of the body confronts orientation of the environment.

Bodies are not the only one that can have an orientation or that can be oriented. These are also theirs (architectural) surroundings. The space itself can be oriented. Oriented architectural space tends to redirect all the bodies that are in it, lining them with itself, being orienting. And, for their part, oriented bodies, by extending into environment, tend to reorient architecture they inhabit. Thus the tension arises. Architecture imprints on body skin, the body imprints on the surface of architecture. They appear together. 
Let us to go back to Lefebvre, and to try to understand this phenomenological body/space tension in the light of his idea of production of space, and his dialectic triad perceived - conceived - lived. It seems to me that the differences in body/space relation between these three necessary states of spatial production are reflected in distinction between the three terms I often use -location, position, and situation. Location is a point described in relation to a conceived space (coordinate, or some other conceptual system). The notion of location corresponds to the abstract representations of space. When we talk over a location of body, our perspective is neutral in terms of the tension that exists between the body and the environment. A located body is determined only by spatial model, and detached from life. In contrast, when we talk about the position, we usually refer to the relationship between body and other surrounding and tangible bodies and objects. Position is a point of perceived space. It is determined by body/space interaction. It appears in a spatial practice, and we see bodies as oriented as much as its (architectural) spaces. Still, a body can be oriented in accordance with the space - thus, in a normal situation, or, on the contrary, it can be situated against its space. Situation is about the way body lives in its space, about what space represents, how it is imprinted. Situation is a point in a space of representation.

Some bodies in the same position can be in a different situation. Orientation devices can become disorientation devices for queer bodies, and vice versa. All the architectonics around LGBT places, mentioned above as opaque membranes, disorients bodies which are to cross the border. Turned away, people on both sides of the border can be confused, hesitating closeted in one way or another.

Speaking of Belgrade, it is clear how opaque membranes of traditional gay cursing places and places of sexual encounter, serve as (dis)orientation devices. In marginal public spaces like these, in public toilets, or in remote areas of city parks, material structure was not enough itself. It had to be supported by coded appearance of bodies. ${ }^{22}$ When it comes to more recent LGBT places, structural disorientation is even more evident. Multilayered membrane around official LGBT places, e. g. bars, pubs, and night clubs, always consisting of several structural inside/outside connections and indirect passages, makes gaping distance from heteronormative public space, and confuses access. ${ }^{23}$

There are many devices in heteronormative field intended to align sex, gender, orientation, practice, and social role; from family, or writing tables, to use of domestic space, or rights to "a room of one's own"24; from streets 
to ghettos; there are orientation devices everywhere ${ }^{25}$. They all make queer body disoriented. However, as normalization makes progress, they lose its disorientation power. The same happens to the surrounding structure of LGBT places. It loses its importance in their formation. The main forces of production of gay places become gravitation and concentration. One of the most famous examples of this kind is Park Slope, a district in Brooklyn, New York. Tamar Rothenberg has taken an analysis of the ways this neighborhood was developed as a residential area of lesbian community, basically through processes of gravitation and concentration. ${ }^{26}$ If there is any disorientation remaining around Park Slope, it is not an effect of some strict structural isolation, but of gradual segregation.

Nowadays, there are some permanent or occasional locations of LGBT concentration in Belgrade, where the architectural structure loses its (dis) orientation power. This is usually the case in particular positions where some queer spatial practice, which is not radically opposed to dominant social norms of that very situation, takes place; for example, when it comes to some cultural events, shopping or recreation. Some shopping malls, film festivals, or music events, have become attractive points of concentration. Nevertheless, regular gay friendly places, places where orientation does not make any difference in the way bodies extend to space, are still fairly hidden.

\section{CONCLUSION}

At the beginning of normalization process, architectural queer space is created from below, as a self-organized practice, and as a lived space. On the other hand, through the work of architectural discipline and its institutions, from above, it is represented as non-extant. In these circumstances, conceived origins of queer space, which has to be architectural, are hidden out of the profession. That is why any research of queer space has to start from lived spatial experiences, instead of starting from an analysis of design. Lefebvre's theory of the production of space is a framework, comprehensive enough to bring together dispersed information, that are out of the discipline. His theory is based on a dialectic triad of perceived, conceived, and lived, or, in spatial terms, triad which interconnects spatial practice, representations of space, and spaces of representations. I accepted the idea that we can research one of these points considering the tension which emerges between the other two.

In research of a certain spatial practice, namely of what is a perceived architectural space, sometimes it is used a metaphor of a device, in order to 
describe an architectural structure. To view architecture as a device is to merge its static model with its dynamic lived mechanism; to link the locations of inhabiting bodies, with their situations; to confront representations of space, to spaces of representation. The subject matter of this paper was to consider two different, but similar devices, which have already existed in theoretical discourse, and to examine how they can work as analytical tools in research of architectural queer space.

The first device was introduced by Beatriz Colomina in her comparative analysis of gendered architectural space of Loos' and Le Corbusier's objects, as a framing device. It has been shown how framing devices form different heteronormative gender positions in the spatial perception. I argued that the framing devices actually work as hiding devices in placement of LGBT, and other non-normative bodies, and in production of queer space. The difference framing devices make between bodies of women and men, creates gapping gay/ straight divide, through collateral processes of marginalization and isolation of subjects/objects, which do not take part in normative gender play.

The second device in question was the one introduced by Sara Ahmed as an orientation device. From phenomenological perspective, Ahmed pointed out how some elements of architecture, such as rooms, or furniture, can produce hetreonormative alignments in lived environment. They can turn, (re)direct and (re)orient the bodies. And, they also can confuse and disorient bodies, by detaching them from their objects. In this respect, I argued that orientation devices can work as disorientation devices. At the beginning of normalization of LGBT identities, numerous disorientations in lives of all the inhabitants are produced by architectural structure. And, the gap is created. What serves to orient someone, disorients others.

It is obvious that devices of perception in architectural space, working in a heteronormative way, simultaneously work in two opposite directions, and produce spatial and social division. Framing devices become hiding ones, orientation devices become disorientation ones. Regarding to experiences in cities and places where normalization of LGBT identities is ahead in development, as the power of framing/hiding and orientation/disorientation devices weakens, the way to freedom is easier. 
An expression used by Sam Vardy, "Spatial agency: tactics of self-organisation," Architectural Research Quarterly 13(02) (2009): 133-140. Blackwell Publishing, 1991).

The original Lefevbre's expression les spaces de representation is translated into English by Donald Nicholson-Smith, using the expression representational spaces, but I sometimes use the expression spaces of representation instead, especially when I want to emphasize the contrast between the two - representations of space and spaces of representation. Neispričane priče iz gej i lezbejskih života, uredile Jelisaveta Blagojević i Olga Dimitrijević. (Beograd: Hartefakt Fond, 2014), 190-209.

Michael P. Brown, Closet space: Geographies of metaphor from the body to the globe (London: Routledge, 2000), 5-20. Bill Hillier and Julienne Hanson, The Social Logic of Space (Cambridge: Cambridge University Press, 1984). Colomina. (New York: Princeton Architectural Press, 1992), 73-130

Sara Ahmed, Queer Phenomenology: Orientations, Objects, Others. (Durham and London: Duke University Press, 2006).

Annamarie R Jagose, Queer Theory: An Introduction. (Melbourne: Melbourne University Press, 1996), 1.

Judith Butler, Gender trouble: feminism and the subversion of identity (New York: Routledge, 1990); Judith Butler, Bodies that matter: on the discursive limits of "sex" (New York: Routledge, 1993); Judith Butler, “Against Proper Objects. Introduction,” differences: A Journal of Feminist Cultural Studies, 6(2-3) (1994): 1-26; Judith Butler, Undoing gender (New York: Routledge, 2004).

My view of identity relies on well-known Anderson's notation of socially constructed community, imagined by the people who perceive themselves as part of that group, sharing the same image. Undoubtedly, this image can be a position or a place. See in Benedict Anderson, Imagined Communities: Reflections on the Origin and Spread of Nationalism, rev. ed. (London: Verso, 1991).

Colomina, "The Split Wall", 95-96.

Ibid., 83.

Michel Foucault, Discipline and Punish: The Birth of Prison, translated by Alan Sheridan (New York: Vintage Books, 1977).

Daphne Spain, Gendered Spaces (London: The University of North Carolina Press, 1992).

Colomina, "The Split Wall", 74.

Ahmed, Queer Phenomenology, 1.

Ibid., 6-7. [emphasis mine]

Ibid., 7. [secondary quotation marks in the original]

Ibid., 12. [secondary quotation marks in the original]

Petar Paunović, "Kako su se beogradski gejevi muvali pre interneta". Noizz. November 10, 2016, accessed December 08, 2016, http://noizz.rs/big-stories/kako-su-se-beogradski-gejevi-muvalipre-interneta/5nhztlz.

Burmaz, „Gej klubovi u Beogradu”, 190-209.

Virginia Woolf, A room of one's own (New York: Harcourt, Brace and Co., 1929).

David Bell and Gill Valentine, "Introduction: Orientations," in Mapping desire: Geographies of sexualities, eds. David Bell and Gill Valentine (London: Routledge, 1995), 1-27.

Tamar Rothenberg, "'And She Told Two Friends': Lesbians Creating Urban Social Space," in Mapping desire: Geographies of sexualities, ed. David Bell and Gill Valentine (London: Routledge, 1995), 150-165. 
Ahmed, Sara. Queer Phenomenology: Orientations, Objects, Others. Durham and London: Duke University Press, 2006.

Anderson, Benedict. Imagined Communities: Reflections on the Origin and Spread of Nationalism. Rev. ed. London: Verso, 1991.

Bell, David, and Gill Valentine. "Introduction: Orientations." In Mapping desire: Geographies of sexualities, edited by David Bell and Gill Valentine, 1-27. London: Routledge, 1995.

Brown, Michael P. Closet space: Geographies of metaphor from the body to the globe. London: Routledge, 2000.

Burmaz, Branko. „Gej klubovi u Beogradu: Unutrašnja periferizacija kvir prostora.” U Među nama: Neispričane priče iz gej i lezbejskih života, uredile Jelisaveta Blagojević i Olga Dimitrijević, 190-209. Beograd: Hartefakt Fond, 2014.

Butler, Judith. Gender trouble: feminism and the subversion of identity. New York: Routledge, 1990.

Butler, Judith. Bodies that matter: on the discursive limits of "sex". New York: Routledge, 1993.

Butler, Judith. "Against Proper Objects. Introduction.” differences: A Journal of Feminist Cultural Studies, 6(2-3) (1994): 1-26.

Butler, Judith. Undoing gender. New York: Routledge, 2004.

Colomina, Beatriz. “The Split Wall: Domestic Voyeurism.” In Sexuality \& Space, edited by Beatriz Colomina, 73-130. New York: Princeton Architectural Press, 1992.

Foucault, Michel. Discipline and Punish: The Birth of Prison. Translated by Alan Sheridan. New York: Vintage Books, 1977.

Hillier, Bill, and Julienne Hanson. The Social Logic of Space. Cambridge: Cambridge University Press, 1984.

Jagose, Annamarie R. Queer Theory: An Introduction. Melbourne: Melbourne University Press, 1996.

Lefebvre, Henri. The Production of Space. Translated by Donald Nicholson-Smith. Oxford: Blackwell Publishing, 1991.

Rothenberg, Tamar. “'And She Told Two Friends': Lesbians Creating Urban Social Space.” In Mapping desire: Geographies of sexualities, edited by David Bell and Gill Valentine, 150-165. London: Routledge, 1995.

Spain, Daphne. Gendered Spaces. London: The University of North Carolina Press, 1992.

Vardy, Sam. "Spatial agency: tactics of self-organisation." Architectural Research Quarterly 13(02) (2009): 133-140.

Woolf, Virginia. A room of one's own. New York: Harcourt, Brace and Co., 1929. 


\section{KOMIKOPOLIS}

\section{Gențiana Cristina Dumitrașcu}

Arhitektonski prezentacija obuhvata jedan render ili seriju rendera, savršeni trenutak, predstavljajući idealizaciju još ne-realizovanog projekta. Šta bi se desilo ako bismo mogli saznati kako je projekat nastao, kako je svaki sloj dodavan dok nije postignut konačni oblik, a prikazani ljudi bi mogli da ispričaju arhitektonski priču?

Fleksibilni hibrid grafičkog medija stripova, koji u svojoj strukturi kombinuje narativni element, prostor i pokret, je oduvek imao jaku vezu sa pojmom arhitekture (simboličkog protagoniste ili čak centralne figure u stripovsko priči). Doktorska disertacija „Komikopolis - Alternativni način prezentacije, razmatranja i projektovanja arhitekture“ analizira kroz teorijske studije, intervjue i eksperimente način na koji karakteristični elementi stripa mogu poboljšati tradicionalnu arhitektonsku prezentaciju i način na koji se ostvaruje interakcija sa arhitekturom i procesom projektovanja prostora.

\section{KONCEPT NAPRAVE KAO ANALITIČKO SREDSTVO U ISTRAŽIVANJU ARHITEKTONSKOG KVIR PROSTORA \\ Branko Burmaz}

Postoje arhitektonske analize prostorne prakse koje se koriste konceptom arhitektonske strukture kao naprave za percepciju. Metafora naprave omogućava da se kombinuju statične reprezentacije prostora sa dinamičnim prostornim iskustvima. U istraživanju arhiektonskog kvir prostora, prostora koji je proizveden kroz samoorganizovane prakse i ignorisan od strane arhitektonske discipline, koncept naprave kao analitičkog sredstva kojim se suprotstavlja življeno i zamišljeno može biti od velike koristi. Ovde razmatram dve različite naprave. Jednu je koristila Beatriz Kolomina (Beatriz Colomina) u svojoj analizi rodnog prostora, nazivajući je naprava za uramljivanje, a druga naprava je naprava za orijentisanje iz „Kvir fenomenologije“ Sare Ahmed (Sara Ahmed). Ono što pokušavam da pokažem je da na početku procesa normalizacije arhitektura, funkcionišući kao naprava za percepciju, proizvodi kvir prostor simultanim mehanizmima uramljivanja i skrivaja, odnosno orijentisanja i dezorijentisanja. Snagom ovih naprava nastaje zjapeća podela u prostou i u društvu.

KLJUČNE REČI: ARHITEKTONSKI KVIR PROSTOR, NAPRAVA ZA URAMLJIVANJE/SKRIVANJE, NAPRAVA ZA ORIJENTISANJE/DEZORIJENTISANJE, PERCIPIRANI PROSTOR, NORMALIZACIJA PROSTORA, PODELA PROSTORA

\section{RAZVOJ PODRUČJA DELTE I BRAJDICE U RIJECI NAKON DRUGOG SVETSKOG RATA: IZMEĐU VIZIJE I STVARNOSTI}

\section{Lidija Butković Mićin}

Formalnopravno ujedinjenje Rijeke i Sušaka po završetku Drugog svetskog rata, u međuraću teritorijalno i upravno samostalnih gradova, nametnulo je pitanje prostornog i funkcionalnog povezivanja dvaju polutki grada. Područje Delte i Brajdice, postupno nasipavano od 1850-ih godina nadalje za potrebe lučkih i željezničkih postrojenja, percipirano je kao dragoceni prostorni resurs za lociranje zgrada administrativne i javne namene te kulturnih, rekreativnih i komercijalnih sadržaja, primerenih novom regionalnom središtu. Članak prezentira urbanističke planove te (ne) realizirane arhitektonske projekte za transformaciju Delte i Brajdice tijekom 1940-ih i 1950-ih godina, koji svjedoče o rastućem raskoraku između vizionarskog urbanizma i realnosti političkoekonomske konstelacije tih desetljeća.

KLJUČNE REČI: RIJEKA, DELTA, BRAJDICA, POSLIJERATNA ARHITEKTURA, POSLIJERATNI URBANIZAM, URBANA REGENERACIJA 